\title{
STRAFFERETTEN OG KAMPEN MOT TERRORISMEN
}

\section{AV PROFESSOR, DR. JURIS ERLING JOHANNES HUSABø}

The fight against terrorism has altered the character of the criminal law. Through Resolution 1373 and the blacklisting of suspected terrorists, the UN Security Council has furthered a globalisation of countermeasures. A European harmonization is promoted by the European Union, especially through the framework decision on combating terrorism. The new criminal provisions are characterized by a broad criminalization of preparatory acts, a wide definition of terrorism, and the distinctive role of the subjective elements of the crime (the terroristic aim). Together, this raises tensions in regard to the principle of legality. The blacklisting of terrorists by the UN and the EU (resulting in the freezing of assets) is in fact a quasi-criminal measure, with a clear lack of legal safeguards for suspected individuals. The present system of international blacklisting infringes on both the presumption of innocence and on the right of access to court. The difficulty of combining effective counter-terrorism measures with respect for basic principles of law is a challenge to criminal law professionals. Since important decisions are taken at the international level, we should contribute to an international debate on these urgent matters.

Kampen mot terrorismen står sentralt på den politiske dagsorden for tida. Terroraksjonen i USA den 11. september 2001 utløyste mottiltak av eit omfang og ei breidde som vi ikkje har sett sidan siste verdskrigen. "Krigen mot terrorismen" har blitt ført på mange plan, både med militære, diplomatiske og rettslege midlar.

Bruken av rettslege verkemiddel er ikkje noko nytt. Dei fleste land har lenge hatt nasjonale reglar som kriminaliserer typiske terrorhandlingar og tek sikte på å sikra effektiv etterforsking og straffeforfølging av slike brotsverk. Dei siste tiåra har det også blitt utarbeidd ei rekkje konvensjonar og andre folkerettslege instrument for å styrkja det internasjonale samarbeidet mot terrorismen. Etter 11. september har utviklinga av terrortiltak skote ny fart, og ført til endringar av regelverket på mange ulike rettsområde, slik som informasjonsutveksling, grensekontroll og innvandringskontroll. Framfor alt er det likevel strafferetten som har vorte gjenstand for endringar. Strafferetten har blitt rekna som eit sentralt verkemiddel for å oppnå den politiske målsetjinga å få bukt med terrorismen.

\footnotetext{
" Title in English: Counter-Terrorism and the Criminal Law. Original in Norwegian.
} 
Det er vanskeleg å vita i kva grad strafferettslege verkemiddel eigentleg kan medverka til ei effektivisering av kampen mot terrorismen. Hovudvekta vil her liggja på ei anna og nærast motsett problemstilling, nemleg kva kampen mot terrorisme har gjort og kan koma til å gjera med strafferetten. Påstanden min er at kampen mot terrorismen har medverka til å endra strafferetten sin karakter og har sett sentrale rettsprinsipp under press. Dette vil eg utdjupa i ti teser om strafferetten og kampen mot terrorismen. Sidan ramma for denne artikkelen er knapp, og eg også i andre samanhengar har drøfta desse spørsmåla, ${ }^{i}$ nøyer eg meg her med ei kortfatta underbygging av kvar av tesane.

\section{Globalisering av strafferetten}

Sikkerhetsrådet i FN vedtok den 28. september 2001 Resolusjon 1373, der rådet gav folkerettsleg bindande pålegg til alle medlemsstatar i FN om å kriminalisera ei rekkje konkrete handlingstypar, frysa dei økonomiske midlane til terroristar, motarbeida rekruttering til terrorgrupper osv. Dette er første gong rådet har nytta dei særskilte fullmaktene etter FN-pakta kapittel VII til å gi generelle og permanente pålegg om lovgiving og rettshandheving når det gjeld eit generelt problem i verdssamfunnet. Slik sett liknar resolusjonen mykje på ein konvensjon, med den vesentlege skilnaden at det er frivillig for ein stat å tiltre konvensjonar.

Ei rekkje av pålegga i Resolusjon 1373 er henta frå tidlegare FN-konvensjonar, særleg konvensjonen frå 1999 om finansiering av terrorisme. ${ }^{\text {ii }}$ Resolusjonen oppmoda samtidig statane til å tiltre både finansieringskonvensjonen og andre konvensjonar om bestemte typar terrorhandlingar. Dessutan oppretta Sikkerhetsrådet eit særskilt underorgan (the Counter Terrorism Committee) til å overvaka statane si gjennomføring av resolusjonen. Komiteen har lagt opp eit omfattande system av rapportering og kommentering som legg press på statane til å gjennomføra pålegga, og som medverkar til å styrkja samordninga av terrorlovgivinga verda over.

Grunntanken bak utviklinga av FN-standarder på dette området er at terroristar ikkje lenger skal ha fristader der dei kan driva planlegging og førebuing, eller gøyma seg unna etter at dei har utført ein terroraksjon. Dette krev også at statane byggjer inn vide jurisdiksjonsreglar i terrorlovgivinga si, noko dei nordiske landa har følgt opp. Samtidig medfører denne globaliseringa av strafferettspleia nye utfordringar for politiet og påtalemakta, slik vi har sett i den såkalla Krekar-saka i Norge.

Eit anna bidrag til globaliseringa er Sikkerhetsrådet si svartelisting av Taliban, Al Quaida, Osama bin Laden og personar og grupper med tilknyting til desse (Resolusjon 1267, 1333 og 1390). Svartelistinga medfører at statarne blir pålagde å "frysa" (bandleggja) alle typar økonomiske verdiar som tilhøyrer dei 
svartelista personane og gruppene, samt å forby all form for $\varnothing$ konomisk samkvem med desse. ${ }^{\text {iii }}$ Dette må etter sin art må kunna kallast eit kvasi-strafferettsleg tvangsmiddel i regi av FN.

\section{EU-harmonisering av strafferetten}

EU utarbeidde allereie den 21. september 2001 ein brei handlingsplan mot terrorisme, og har sidan spela ei leiande rolle i utviklinga av anti-terror tiltak i Europa. ${ }^{\text {iv }}$ Fokuset på terrorisme har medverka til ei framskunding og vidareutvikling av dei planane for politi- og strafferettssamarbeid som vart lagt på toppmøtet til Det europeiske rådet i Tammerfors i $1999 .{ }^{v}$ Det har mellom anna framskunda gjennomføringa av prinsippet om gjensidig anerkjenning av strafferettslege avgjerder, med den europeiske arrestorde som det viktigaste dømet. ${ }^{\mathrm{vi}}$

Av meir spesifikke terrortiltak må særleg nemnast rammeavgjerda mot terrorisme som vart vedteken 13. juni 2002. ${ }^{\text {vii }}$ Rammavgjerda følgjer opp og samordnar EU-statane si gjennomføring av påbodet om kriminalisering i Resolusjon 1373. Særleg viktig er definisjonen av "terroristic offences" (art. 1). Sidan FN til no ikkje har samla seg om ein fulldekkande definisjon av fenomenet, kan EUdefinisjonen koma til å bli retningsgivande også for land utanfor EU, ${ }^{\text {vii }}$ samt på det folkerettslege planet. Men rammeavgjerda let vera å ta stilling til enkelte av dei spørsmåla som har vore kontroversielle ved definisjonen av terrorisme, mellom anna om det gjeld noko unntak for folkegrupper som kjempar ein legitim frigjeringskamp. ${ }^{\text {ix }}$

Rammeavgjerda pålegg ikkje berre statane å kriminalisera terroristiske brotsverk, men også at desse skal bli "deemed as such". Ei slik plikt til å setja ein bestemt merkelapp på eit brotsverk i den nasjonale lovgivinga, har ikkje vore vanleg korkje i konvensjonar eller i tidlegare rammeavgjerder innanfor EU. Grunnen til kravet om "merking" i nasjonal lovgiving er truleg at det vil kunna forenkla samordninga av andre typar rettslege tiltak mot terrorisme.

Etter rammeavgjerda må statane også kriminalisera forsøk på terrorisme og alle former for medverking (art. 4), samt to grupper av førebuingshandlingar. For det første skal tre slag vanlege brotsverk (grovt tjuveri, utpressing og framstilling av falske administrative dokument) reknast som "offences linked to terrorist offences" (art. 3) dersom dei er gjort med formål om å utføra eit terrorbrotsverk. For det andre skal statane kriminalisera "offences related to a terrorist group" (art. 2), både det å leia og delta i ei slik gruppe (inkludert alle former for finansiering). Dette grepet med å knyta kriminaliseringa av førebuingshandlingar til eksistensen av ei terrorgruppe, finn ein ikkje i Resolusjon 1373. Det samsvarar likevel godt med ein internasjonal tendens i retning av å fokusera meir på organisert kriminalitet og kriminelle grupper. ${ }^{x}$ 
Under utforminga av rammeavgjerda vart det arbeidd for å få til ei sterk samordning også av strafferammene. Men i det endelege vedtaket vart dette noko avdempa. Rammeavgjerda nøyer seg med å fastsetja at terroristbrotsverk skal kunna straffast strengare enn det som ville vore strafferamma om handlinga ikkje hadde hatt eit terroristisk formål. Når det gjeld leiing av og deltaking i ei terroristgruppe er rammeavgjerda likevel meir konkret. Maksimumsstraffa skal vera minst 15 års fengsel for å leia ei slik gruppe, og minst 8 år for deltaking elles.

EU spelar også ei viktig rolle når det gjeld svartelistinga av bestemte terroristar og terrorgrupper. Medan Norge har implementert pålegga frå Sikkerhetsrådet gjennom nasjonal lovgiving, har EU-statane gjort det same gjennom overnasjonal lovgiving. EF-forordning 881/2002 (tidlegare 467/2001) gir pålegg om frysing av alle midlar tilhøyrande personar og organisasjonar som står på FN si "Taliban-liste", og forbyr all form for økonomisk samkvem med dei som er svartelista. Kva sanksjonar som skal gjelda dersom det sistnemnde forbodet blir brote, vert det overlate til nasjonal lovgiving å fastsetja.

EU har dessutan innført eit eige system med svartelisting som kjem i tillegg til Taliban-lista. Denne meir generelle svartelista er eit ledd i gjennomføringa av Resolusjon 1373, og omfattar ei rekkje andre mistenkte terroristar og terrorgrupper enn dei som står på Taliban-lista. Også her er frysinga og forbodet mot $\emptyset$ konomisk samkvem gjennomført ved ei EF-forordning (2580/2001), med tilhøyrande nasjonal sanksjonering. Denne forordninga gjeld i praksis berre for personar og grupper som ikkje har ei direkte tilknyting til eit EU-land.

Når vi ser EU-tiltaka mot terrorisme i samanheng, framstår desse som ein såkalla "cross-pillar action". xi Vedtaka om å implementera Resolusjon 1373 og innføra svartelister er gjort med basis i EU si andre søyle, den felles utanriks- og tryggingspolitikken (EU-traktaten del V). Svartelistinga er gjennomført under EU si første søyle (EF-traktaten), medan rammeavgjerda høyrer under tredje søyle (EU-traktaten del VI). Denne typen samordning av tiltak gir EU større slagkraft, og peikar fram mot den integreringa av den noverande søylestrukturen som forslaget til ny EU-konstitusjon legg opp til.

\section{Strafferetten får ein meir "pre-aktiv" karakter}

Tradisjonelt vert strafferetten aktivert etter at eit brotsverk har skjedd (re-aktiv strafferett). Problemet med terrorisme illustrer at det også er eit legitimt behov for å kunna avverja alvorlege handlingar på førehand. I den grad ein forsøker å bruka strafferetten til dette, kan vi tala om ein "pre-aktiv" strafferett. ${ }^{\text {xii }}$

Innføringa av nye terror-reglar etter 11. september har forsterka ein allereie merkbar tendens til ei slik endring av strafferettens karakter. For det første har vi fått ei vidare og hardare kriminalisering av ulike typar førebuingshandlingar. Dette gjeld ikkje berre kriminaliseringa av dei førebuingshandlingane som EU si 
rammeavgjerd omfattar, jf framanfor. Fleire av dei nordiske landa har, som eit ledd i gjennomføringa av Resolusjon 1373 og terrorfinansieringskonvensjonen, vedteke andre og meir vidtgåande straffereglar mot finansiering og andre typar førebuing av terrorisme. .iii $^{\text {in }}$

Ein sekundær effekt av den "pre-aktive" kriminaliseringa er å opna opp for bruk av inngripande etterforskingsmetodar på eit tidlegare stadium av den forbryterske verksemda, sidan bruken av slike metodar etter prosessreglane vanlegvis er betinga av at det er ein grunngitt mistanke om noko som utgjer eit straffbart forhold. Denne verknaden er truleg viktigare enn sjølve den "pre-aktive" kriminaliseringa, sidan det er langt oftare at førebuingskriminalitet blir etterforska enn at det vert reist straffesak for slike handlingar. Det pågår dessutan ein diskusjon i fleire land om å gi politiet eller overvakingstenesta reint førebyggjande fullmakter til å bruka telefonavlytting, romavlytting osv., utan at det skal gjelda noko vilkår om skjellig grunn til mistanke om eit (allereie) straffbart forhold. ${ }^{x}$

Ei tredje side ved den "pre-aktive" dreiinga av strafferetten er at også sanksjonering skjer før det eigentlege brotsverket er utført. Dette kan skje i form av ein vanleg straffedom for førebuingskriminalitet, og er då ein direkte konsekvens av den "pre-aktive" kriminaliseringa. Men det synest som det i praksis ofte er vanskeleg å føra tilstrekkelege bevis for førebuingskriminalitet til å oppnå ein fellande dom. Dette gjeld nok også i terrorsaker, og kan vera ei medverkande årsak til at det på dette området har vakse fram andre former for sanksjonering på eit førebuande stadium, basert på ein lågare grad av mistanke om terrorførebuing. Frysinga av dei økonomiske midlane til mistenkte terroristar fungerer i realiteten som ein tung økonomisk sanksjon, sidan reaksjonen innanfor EU kan stå ved lag på ubestemt tid og det ikkje er nokon føresetnad at frysinga vil bli etterfølgt av ei straffesak. Den mest vidtgåande "pre-aktive" sanksjoneringa er likevel interneringa av "suspected international terrorists" i Storbritannia, også denne basert på lågare mistankekrav enn ein vanleg straffereaksjon og utan ei bestemt tidsramme. $^{\mathrm{xv}}$

\section{Subjektivering av straffansvaret}

Ei anna side ved dei nye straffereglane mot terrorisme er ein tendens til større "subjektivering" av straffeansvaret. Med dette siktar eg til at personen si subjektive innstilling, i form av forsett, hensikt eller motiv, får ei meir dominerande rolle i kvalifiseringa av eit brotsverk. Tradisjonelt har dei subjektive elementa ein subsidiær funksjon, ved at vi først spør etter personen sitt forsett dersom han oppfyller dei objektive kjenneteikna på eit brotsverk (gjerningsskildringa). Ved dei nye terror-relaterte brotsverka synest dette delvis endra. 
Etter EU sin definisjon av terrorbrotsverk (rammeavgjerda art. 1) må brotsverket ha blitt "committed with the aim of:

- seriously intimidating a population, or

- unduly compelling a Government or international organisation to perform

or abstain from performing any act, or

- seriously destabilising or destroying the fundamental political, constitutional, economic or social structures of a country or an international organisation"

Dogmatisk sett fungerer dette vilkåret som eit subjektivt overskot. Det er eit subjektivt vilkår som kjem i tillegg til det ordinære kravet om at personen utførte primærbrotsverket (t d ei kidnapping eller eit drap) med forsett. Rammeavgjerda sin bruk av uttrykket "aim" (på svensk"syfte", på dansk "formål") indikerer at det dreier seg om noko anna enn eit vanleg forsett. Ved eit vanleg forsettskrav er det personen sin vilje og kunnskap i relasjon til den konkrete handlinga som står $\mathrm{i}$ fokus, jf uttrykket "gjorde det med forsett". Tilleggsvilkåret i rammeavgjerda knyter seg derimot til personen sitt bakanforliggjande motiv med handlemåten. ${ }^{\text {xvi }}$

Ved fullførte terrorbrotsverk spelar motivet berre ei rolle for strafferamma, sidan primærbrotsverka også er straffbare utan eit terroristisk motiv. Det same gjeld ved såkalla "offences linked to terrorist activities", jf punkt 3 framanfor. Den mest avgjerande rolla spelar motivet ved kriminaliseringa av førebuingshandlingar. Der mest alle typar førebuing av terrorisme er straffbar, slik som etter svensk og dansk rett, ${ }^{\text {xii }}$ blir det først og fremst forsettet og motivet som skil dei lovlege handlingane ( $\mathrm{t} d$ innkjøp av ein kniv) frå dei ulovlege. Det same gjeld der ein har gått langt $\mathrm{i}$ å kriminalisera finansiering av terrorisme, slik som den norske straffelova $\S 147 \mathrm{~b}$. ${ }^{\text {xiii }}$ Der er det eksistensen av eit "terrorforsett", eller kjennskap til at mottakaren har "terrorforsett", som bestemmer kva som er lovleg og ulovleg innsamling eller overlevering av pengar. ${ }^{\text {xix }}$ Eksistensen av eit "terrorforsett" vil dessutan indirekte vera avgjerande for om visse tvangsmidlar kan nyttast på etterforskingsstadet. Dette har samanheng med at bruken av slike midlar ( $\mathrm{d}$ telefonavlytting) er gjort betinga av at det er mistanke om eit brotsverk med ei viss minste strafferamme, eit krav som gjerne berre er oppfylt der handlemåten kan reknast som førebuing til terrorisme. ${ }^{\mathrm{xx}}$

Den rolla som det terroristiske motivet eller "terrorforsettet" har, må sjåast i lys av vanskane med bevisføring for subjektive forhold generelt. Sjølv om det ikkje alltid ligg føre direkte bevis for om personen utførte brotsverket med (vanleg) forsett, $\mathrm{t} d$ om han drap med vitande og vilje, let dette seg ofte utleia av handlinga sin karakter og omstenda rundt. Derimot vil personen sitt subjektive motiv for ei handling ikkje like lett kunna utleiast av den ytre handlinga. Det er då nærliggjande å nytta miljøet rundt personen som indisium på kva motiv han eller ho hadde, noko som inneber ein klar fare for å gjera mistenkte personar urett. 


\section{Internasjonale organisasjonar tøyer fullmaktene sine}

Etter folkeretten er fullmaktene til ein internasjonal organisasjon avleidd frå statane sin suverenitet. ${ }^{x i}$ Organisasjonen må difor handla innanfor rammene av den traktaten som konstituerer organisasjonen. Både FN og EU har på enkelte punkt strekt grensene for kompetansen sin så langt at ein kan spørja om dei har gått utanfor fullmaktene sine.

Den lovgivarrolla som Sikkerhetsrådet tok i og med Resolusjon 1373 er problematisk av to grunnar. Resolusjonen er ikkje relatert til ein konkret situasjon som truar verdsfreden, slik art. 39 i FN-pakta synest å krevja, men gjeld eit generelt problem i verdssamfunnet (internasjonal terrorisme). Dessutan er det å fastsetja generelle krav til statane si lovgiving og rettshandheving ein annan type verkemiddel enn det som er føresett i art. 41 og som Sikkerhetsrådet tidlegare har teke i bruk. På liknande måte kan det hevdast at det å sanksjonera enkeltindivid, slik det blir gjort gjennom Taliban-lista, er verkemiddel av ein heilt annan karakter enn det som Sikkerhetsrådet var tiltenkt då FN-pakta vart vedteken. Sidan både svartelistinga og Resolusjon 1373 er følgt lojalt opp av dei aller fleste statar, er det kanslije vanskeleg å hevda at vedtaka i dag er ugyldige. Det er likevel grunn til å peika på at samansetjinga av Sikkerhetsrådet og rådet sin arbeidsmåte gjer det lite eigna både til å fungera som verdslovgivar og til å sanksjonera enkeltindivid basert på strafferettsleg mistanke.

EU sin kompetanse til å svartelista enkeltpersonar har også blitt trekt i tvil. ${ }^{\text {xii }}$ Det heimelsgrunnlaget som forordningane byggjer på er EF-traktaten art. 301 (jf art. 60) og art. 308. Artikkel 301 gir heimel til å sanksjonera "third countries" når dette skjer på grunnlag ei felles haldning under andre søyle. Men ein må tøya ordlyden svært langt for å koma til at regelen også gir heimel til å innføra økonomiske sanksjonar mot enkeltpersonar heimehøyrande i tredjeland, sjølv personar utan tilknyting til styresmaktene i landet. Særleg problematisk i høve til art. 301 er den sanksjoneringa av enkelte EU-borgarar som har skjedd med basis i Taliban-lista.

Artikkel 308 er ei meir generell fullmakt for Ministarrådet til å fastsetja nærare reglar om eit emne, der EF-traktaten ikkje har nokon spesiell heimel som ein kan nytta. Men art. $308 \mathrm{krev}$ at tiltaket er " necessary to attain, in the course of the operation of the common market, one of the objectives of the Community". Desse måla er opprekna i EF-traktaten art. 2, 3 og 4, og fokuserer på økonomiske aktivitetar, sysselsetjing, sosial velferd osv. Utanriks- og tryggingspolitikk er ikkje eigne formål under EF-traktaten, berre under EU-traktaten.

Fleire av dei personane som er ramma av EU-reglane om svartelisting har reist sak for EF-domstolen. ${ }^{\text {xiii }}$ Det gjenstår difor å sjå om domstolen vil godta den vide tolkinga av EF-traktaten som forordningane er bygt på. Uansett synest det som om heller ikkje EU-regelverket er tilpassa til denne typen tvangsmiddelbruk overfor mistenkte kriminelle. 


\section{Press på legalitetsprinsippet}

Eit sentralt problem ved "pre-aktiv" kriminalisering er det kravet til tydeleg straffeheimel som ligg innebygd i legalitetsprinsippet. ${ }^{\text {xxiv }}$ Definisjonen av terrorisme har blitt kritisert for å vera vid og vag. Særleg gjeld dette uttrykka (i rammeavgjerda) "the fundamental ... social structures of a country" og "international organisation". Som nemnt let rammeavgjerda dessutan viktige avgrensingsspørsmål stå opne. Sidan rammeavgjerda har blitt implementert nokså ordrett, har desse uklare aspekta ved rammeavgjerda forplanta seg i den nasjonale lovgivinga. Vanskane blir forsterka ved at føresegnene om jurisdiksjon er vide i desse tilfella. Det er ikkje like lett å seia kva som er dei grunnleggjande samfunnsstrukturane i Afghanistan som i Finland.

Når det gjeld fullførte terrorbrotsverk har definisjonen av terrorisme rett nok berre betydning for strafferamma, sidan handlingane også er straffbare utan "terrorforsett". Slik sett kunne ein tru at omsynet til legalitetsprinsippet er mindre viktig her. Men definisjonen av terrorisme er også sentral i kriminaliseringa av førebuingshandlingar. Mange av dei handlingane som inngår i førebuinga av kriminell verksemd er daglegdagse handlingar som isolert sett ikkje skil seg frå fullt legitim verksemd. Dersom ein kriminaliserer førebuing til terrorisme generelt, slik ei ordlydstolking av Resolusjon 1373 tilseier, gir straffebodet difor svak rettleiing om grensa mellom rett og urett. Denne problemstillinga har ein vore merksam på i alle dei nordiske landa, men drege noko ulike konsekvensar av. ${ }^{\text {xxv }}$ I Norge var omsynet til legalitetsprinsippet medverkande til at ein valde å berre kriminalisera førebuing i form av å inngå "Forbund" (avtale) om terrorisme. Men den norske strafferegelen mot finansiering av terrorisme ( $\$ 147 \mathrm{~b})$ er framleis så vid at det kan vera problematisk for ein person å føresjå rettsstillinga si. ${ }^{\text {xxi }}$

Det avhjelper ikkje det problematiske i høve til legalitetsprinsippet at lovgivar i desse tilfella har kompensert den svake objektive karakteristikken av det straffbare med å stilla ekstraordinære subjektive krav (jf punkt 5 framanfor). Folk bør kunna føresjå kva handlemåtar som er straffbare, ikkje berre kva motiv det er ulovleg å ha når ein handlar. Sidan vurderinga av bevis om subjektive forhold er mindre handfast, vil det dessutan ikkje alltid vera så lett å føresjå kva motiv ein dommar kjem til at ein har hatt.

\section{Press på uskuldspresumsjonen}

Systemet med svartelisting av mistenkte terroristar er problematisk i høve til eit anna grunnleggjande rettsstatsprinsipp for straffesaker: at einkvar skal reknast som uskuldig inntil det motsette er bevist. ${ }^{\text {xxvii }}$ I EMK art. 6 (2) er det uttrykt slik: "evereyone charged with a criminal offence shall be presumed innocent until proved guilty according to law". 
Svartelistinga i regi av FN eller EU skjer vanlegvis på grunnlag av etterretningsinformasjon frå eit eller fleire land, utan at det ligg føre nokon dom mot personen, og utan noko form for kontradiksjon. Då er det ikkje ført skuldbevis "according to law". Til forsvar for svartelistinga vil ein gjerne hevda at det er eit reint preventivt tiltak, og at personen difor ikkje er "charged with a criminal offence". Likevel er det fleire grunnar for å rekna dette vilkåret som oppfylt her. ${ }^{\text {xxviii }}$ Frysinga er basert på ein mistanke om at personen er involvert i alvorlege straffbare handlingar (terrorisme). Personen sin $\emptyset$ konomiske handlefridom blir blokkert. Han kan korkje bruka dei midlane han har eller få tilført nye midlar. Frysingsvedtaket har inga tidsavgrensing. Dessutan inneber svartelistinga (som ordet seier) at personen blir stempla som ein samfunnsfiende.

Så langt har svartelistinga i regi av FN og EU (og den nasjonale implementeringa) mykje til felles med eit frysingsvedtak som er gjort nasjonalt, til dømes etter reglane om bandlegging av formuesgode i den norske straffeprosesslova kap. 15b. ${ }^{\text {xix }}$ Men det siste er eit tidsavgrensa straffeprosessuelt verkemiddel som føreset at skuldspørsmålet skal avgjerast av ein domstol i ei etterfølgjande straffesak, om ikkje mistanken vert svekt undervegs slik at saka blir lagt bort. Ein slik føresetnad ligg ikkje innebygd i systemet med svartelisting i regi av FN eller EU. Difor framstår denne svartelistinga i realiteten som ei skuldkonstatering.

\section{Utholing av retten til domstolsproving}

Eit tredje rettsstatleg prinsipp er retten til domstolsprøving, som etter EMK art. 6 (1) gjeld både ved avgjerd av "criminal charge" og "civil rights and obligations". Det kan ikkje vera tvil om at svartelistinga i det minste er avgjerande for personen sine sivile rettar. Det er langt større grunn til tvil om systemet med svartelisting ivaretek denne retten. ${ }^{\mathrm{xx}}$

Når det gjeld svartelistinga i regi av Sikkerhetsrådet, finst det ingen domstol på FN-nivå som individ kan klaga vedtaket inn for. Ein kan heller ikkje klaga FN inn for nasjonale domstolar, på grunn av organisasjonen sin immunitet. Den einaste måten ein svartelista person kan søka ei rettsleg overprøving av oppføringa på ei FN-liste, er difor å reisa sak anten mot EU eller mot nasjonale organ som har gjennomført Sikkerhetsrådet sitt pålegg.

I EU-landa er EU-domstolen den mest nærliggjande instansen å venda seg til, sidan både FN-svartelista og EU si eiga svarteliste er gjennomført ved ei EFforordning. Det er ikkje tvil om at svartelista personar har søksmålskompetanse. Spørsmålet er om EU-domstolen har høve til, og i praksis vil føreta, ei tilfredsstillande prøving av denne typen saker. EU-domstolen har så langt ikkje har teke stilling til desse spørsmåla, men som nemnt ventar fleire saker på ei avgjerd. Her nøyer eg meg difor med å peika på enkelte sentrale problemstillingar. 
Eit alvorleg problem ved svartelistinga i regi av Sikkerhetsrådet, er at avgjerda om å føra ein person opp på lista ikkje byggjer på subsumsjon under ei generell norm. ${ }^{\text {xxxi }}$ Sidan det ikkje er noko kriterium å vurdera bevisa opp mot, er det knapt mogeleg for nokon domstol (korkje nasjonalt eller på EU-nivå) å avgjera om ein bestemt person vart ført opp på lista med rette eller urette. Dette problemet gjeld ikkje EU si svarteliste, for der er det gjort klart at oppføringa skal byggja på mistanke om deltaking i terrorisme, slik dette er definert innanfor EU. ${ }^{\text {xxxii }}$

Eit meir generelt problem er at EU-domstolen og prosedyren der er utvikla for andre sakstypar. ${ }^{\text {xxxiii }}$ Det høyrer ikkje til denne domstolen sin kvardag å vurdera bevis om påståtte straffbare forhold utført av enkeltpersonar. Særleg synest domstolen lite eigna til å overprøva den typen etterretningsinformasjon som oppføringa på ei svarteliste vanlegvis byggjer på. Det er dessutan tvilsamt om nasjonale etterretningsorgan som har lagt fram informasjon om ein mistenkt terrorist til denne staten sine representantar i EU, vil vera villig til å dela denne informasjonen med EU-domstolen. Det kan vera vanskeleg nok å få fram bevisgrunnlaget når slike saker vert ført for nasjonale domstolar, sjølv om ein der har særlege prosessreglar som er tilpassa den sensitive karakteren til denne typen saker.

Det er også tenkeleg at ein svartelista person eller organisasjon kan reisa sak for nasjonale domstolar. Han kan $\mathrm{t} d$ forsøka å reisa sak mot dei nasjonale styresmaktene som har føreslått svartelistinga, men då må saka reisast $\mathrm{i}$ vedkomande land (t d USA eller Storbritannia). Alternativt kan han reisa sivil sak mot den banken e.l. som set i verk frysinga og nektar å frigi sparekapital eller andre formuesgode som tilhøyrer den svartelista. På grunn av bevisa sin særeigne og sensitive karakter er det likevel vanskeleg å tenkja seg ei tilfredsstillande overprøving i ei sivil sak av bevisgrunnlaget for at personen er blitt svartelista. Derimot kan ein tenkja seg at ein nasjonal domstol i ei slik sak kan prøva det generelle heimelsgrunnlaget for svartelistinga og frysinga av midlar. Sidan svartelistinga i EU-landa er vedteke gjennom EF-forordningar, må den nasjonale domstolen i så fall be EU-domstolen om ei rådgivande fråsegn om tolkinga av EFtraktaten.

Ved innføringa av svartelister i regi av FN og EU synest det som ein har oversett individet sin rett til domstolsprøving. Kontrasten er stor til det systemet med bandleging (frysing) av formuesgode som er etablert i den norske straffeprosesslova $§ 202 \mathrm{~d}$ flg. Her har ein lagt inn ein obligatorisk domstolskontroll innan sju dagar, med visse særeigne prosedyrereglar som er tilpassa sakstypen sin sensitive karakter. 


\section{Press på maktfordelingprinsippet}

Ein grunnleggjande idé som ligg bak både legalitetsprinsippet og retten til domstolsprøving er prinsippet om maktfordeling mellom den lovgivande, ut $\varnothing$ vande og dømmande makta. Prinsippet er tenkt innanfor ramma av nasjonalstaten, og er ikkje utan vidare lett å overføra til EU-nivå eller til verdssamfunnet. Her skal eg nøya meg med å peika på korleis FN og EU si ekspansive rolle i kampen mot terrorisme har endra maktfordelinga mellom dei tre statsmaktene på nasjonalt plan.

FN si lovgivarrolle gjennom Resolusjon 1373 avgrensa handlefridomen til dei nasjonale parlamenta då den nye terrorlovgivinga skulle vedtakast. For dei landa som er med i EU har rammeavgjerda mot terrorisme ytterlegare avgrensa handlefridomen. Før rammeavgjerda vart vedteken, vart ho rett nok lagt fram for dei nasjonale parlamenta. Men då var forhandlingane avslutta og spelerommet for å koma med endringsforslag svært lite. ${ }^{\text {xxxiv }}$ Svartelistinga i regi av FN har også avgrensa makta til dei nasjonale parlamenta. Dei har blitt pålagde å gjennomføra Sikkerhetsrådet sine vedtak, utan å ha nokon innverknad på kva generelle kriterium som skal gjelda for svartelistinga.

Når justispolitikken på denne måten blir utanrikspolitikk, får den utøvande makta samtidig ei utvida rolle. Gjennom medlemsskapet i Sikkerhetsrådet i 2001-2002 hadde den norske regjeringa, i alle fall i teorien, makt til å påverka innhaldet i Resolusjon 1373 og 1390 (om svartelisting). Den danske, svenske og finske regjeringa var med på å forhandla fram EU-rammeavgjerda om terrorisme og vedta denne i Ministarrådet. Sameleis er det den utøvande makta i dei enkelte EU-landa som har føreslått og vore med på å avgjera kva organisasjonar og personar som skal stå på EU si svarteliste.

Dei nasjonale domstolane synest å vera den største taparen i systemet med internasjonale svartelister. Sidan svartelistinga reelt sett har karakter av eit kvasistrafferettsleg tvangsmiddel, burde domstolane vore trekte inn i ei obligatorisk rettsleg prøving av dei individuelle vedtaka, slik systemet er etter den norske straffeprosesslova $\S 202 \mathrm{~d}$ flg. Ved svartelistinga i regi av FN og EU er dei i staden sette heilt utanfor. Sidan vedtaka her blir treft på overnasjonalt nivå, er det som vi har sett også usikkert om dei nasjonale domstolane vil kunne utøva ein effektiv etterkontroll, dersom svartelista personar reiser sak. Men domstolane si uavhengige stilling gjer at dei, dersom viljen er til stades, kan skjera gjennom ansvarspulveriseringa og utøva ein effektiv legalitets- og rettstryggleikskontroll.

Den vide definisjonen av terrorisme overlet mykje av ansvaret for grensedraginga til domstolane. Slik sett kan dei koma til å få ei politisk kontroversiell oppgåve, dersom dei først får slike saker på bordet. Den i praksis viktigaste skjønnsutøvinga ligg nok likevel også her hjå den utøvande makta (påtalemakta), som bestemmer om ein skal innleia etterforsking og reisa sak. Særleg må ein 
rekna med at det vil bli praktisert eit vidt skjønn der den påståtte terrorhandlinga har lita eller inga tilknyting til landet, og det er spørsmål om å nytta reglane om universell jurisdiksjon. ${ }^{\mathrm{xxxv}}$

\section{Faglege og kriminalpolitiske utfordringar}

Kampen mot terrorismen stiller det strafferettslege fagfeltet overfor ei rekkje nye utfordringar. På den eine sida er det utan tvil eit sterkt behov for internasjonal samordning av tiltak mot terrorisme, også av den strafferettslege og straffeprosessuelle lovgivinga. Sameleis er det eit klart behov for "pre-aktive" mottiltak, først og fremst i form av ei effektiv etterretningsteneste. På den andre sida står fleire av dei strafferettslege og kvasi-strafferettslege tiltaka som er blitt gjennomførte i eit spenningsforhold til grunnleggjande rettsstatsprinsipp.

I denne situasjonen er det eit stort behov for fagkunnskap. For det første er det viktig å unders $ø$ ka om dei strafferettslege tiltaka som er gjennomførte, faktisk medverkar til ein meir effektiv kamp mot terrorismen. Det er til dømes grunn til å spørja om kriminalisering av førebuingshandlingar er eit så effektivt verkemiddel i kampen mot terrorismen som det gjerne har blitt framstilt som. Vidare er det eit sterkt behov for ein meir generell analyse av korleis behovet for ein meir "pre-aktiv" strafferett kan sameinast med omsyna bak legalitetsprinsippet, samt korleis subjektiveringa av straffansvaret påverkar bevisvurderinga $\mathrm{i}$ straffesaker.

Den internasjonale svartelistinga av mistenkte terroristar reiser heilt særeigne utfordringar. Slik som systemet med svartelisting er innretta i dag, særleg FN-svartelistinga, sviktar dei mest basale rettstryggleiksgarantiane for den enkelte, først og fremst retten til ei effektiv domstolsprøving. Etter mitt syn bør denne typen sanksjonering av enkeltindivid skje på nasjonalt nivå, fordi det (for tida) berre er her vi har innebygt dei nødvendige straffeprosessuelle garantiane. ${ }^{x x v i}$

Frykta for terrorisme er framleis høgst reell, sameleis krava om radikale mottiltak. Vi må difor rekna med at presset mot dei grunnleggjande rettsprinsippa vil halda fram. Dette gjer det nødvendig med ein løpande diskusjon om vegen vidare. Men når reglane blir til på regionalt eller globalt nivå, eller rammene blir lagt der, treng vi treng ein annan type kriminalpolitisk debatt enn før. Det må setjast eit sterkare søkelys på korleis det enkelte landet si regjering opptrer internasjonalt, når nye strafferettslege tiltak blir til. Dessutan må diskusjonen i større grad førast i internasjonale fora, medrekna det nordiske kriminalistmøtet. 


\section{Noter:}

'Sjå nettida til forskingsprosjektet "Pre-aktiv strafferett"

(http://www.jur.uib.no/ansatte/joreh/Temasider/Temaside_3.html), særleg artikkelen "The implementation of new rules on terrorism through the pillars of the European Union". Sjå også http://www.jur.uib.no/ansatte/joreh/Temasider/Temaside_2.html, der ein finn lenkjer til folkerettslege dokument i kampen mot terrorismen, samt nye lovreglar, førearbeid $\mathrm{m} v \mathrm{i}$ fleire land.

ii International Convention for the Suppression of the Financing of Terrorism, vedteken av Generalforsamlinga 09.12.99, GA Res. 54/109.

iii Over 300 personar og over 100 "entities" er ført opp på lista, jf http://www.un.org/Docs/sc/committees/1267/1267ListEng.htm.

iv Jf Brussels Extraordinary European Council: Conclusions and Plan of Action, 21.09.01, Press release Nr. 140/01. Etter terroraksjonen i Madrid den 11. mars 2004 er ein ny plan lagt fram, jf Brussels European Council, Declaration on combating terrorism, 25.03.04.

" Jf Nuotio, Nordisk Tidsskrift for Kriminalvidenskab 2001 (4) s. 297 og Lahti, Nordisk juristmøte 2002 (I) s. 438-439.

${ }^{v i}$ Council Framework decision of 13 June 2002 on the European arrest warrant and the surrender procedures between the Member States, OJ 2002 L 190/1.

vii Council Framework Decision of 13 June 2002 on combating terrorism, OJ 2002 L 164/3.

viii Det dåverande utkastet til rammeavgjerd påverka såleis utforminga av den norske strafferegelen om terrorisme, jf Ot.prp. nr. 61 (2001-2002) s. 26-27.

${ }^{\text {ix }}$ Dette er rett nok teke opp i eit Council Statement (109/02) som vart vedteke same dag som rammeavgjerda. Men dette dokumentet har ingen formell status i EU-retten.

x Jf særleg United Nations Convention against Transnational Organized Crime, vedteken av Generalforsamlinga 15.11.2000, som definisjonen av ei terrorgruppe synest å vera henta frå.

${ }^{x i}$ Jf Denza, The intergovernmental pillars of the European Union, Oxford 2002 kap. 8.

xii Sjå nærare Husabø, Tidsskrift for Strafferett 2003 (1) s. 96-107.

xiii Jf den norske straffelova § 147a fjerde ledd (inngåing av "Forbund" om å utføra terrorisme) og § $147 \mathrm{~b}$ (finansiering av terrorisme), den danske straffelova $\S 114 \mathrm{a}$ (finansiering av terrorisme), den svenske Lag (2002:444) om straff för finansiering av särskilt allvarlig brottslighet i vissa fall, m.m. § 3 og Lag (2003:148) om straff för terroristbrott $\S 4$ (försök, förberedelse eller stämpling till samt underlåtenhet att avslöja terroristbrott), og den finske straffelova kap. 34a § 2 (förberedelse till brott som begås i terroristiskt syfte) og $\S 5$ (finansiering av terrorism).

xiv Jf NOU 2004: 6 (Mellom effektivitet og personvern. Politimetoder i forebyggende øyemed), som i kap. 8 også gir oversikt over rettstilstanden i dei andre nordiske landa.

xv Jf The Anti-terrorism, Crime and Security Act 2001, del IV. Denne interneringa ("detention"), som har gjort det nødvendig med ein derogasjon frå den Europeiske menneskerettskonvensjonen (jf art. 15), er omstridd. Jf Fenwick, The Political Quarterly 2002 s. 80-104 og Black-Branche, European Law Review 2002 (Human Rights Survey) s. 19-32.

xvi Jf Van der Wilt, Het terroristische oogwerk, i: Dolman, Terrorisme, Europa en strafrecht, Amsterdam 2003 s. 55-81.

${ }^{x v i i}$ For dansk rett sjå den vide forsøksdefinisjonen i § 21 og for svensk rett sjå Lag (2003:148) om straff för terroristbrott $\S 4$ (förberedelse eller stämpling till samt underlåtenhet att avslöja terroristbrott )

${ }^{\text {xviii }}$ Særleg $§ 147 \mathrm{~b}$ andre ledd går langt i kriminaliseringa. Denne regelen er meir vidtgåande enn terrorfinansieringskonvensjonen krev, og tek sikte på å gjennomføra Resolusjon 1373 art. 1 (d). Den danske § 114a synest å vera om lag like vid.

${ }^{\text {xix }}$ Den norske terrorparagrafen (straffelova $\$ 147 a$ ), stiller krav om eit av tre alternative "forsett", der EU si rammeavgjerd stiller tilsvarande krav til "aim". 
${ }^{\mathrm{xx}} \mathrm{Jf}$ for norsk rett Ot.prp. nr. 61 (2001-2002) s. 51.

xxi Jf Klabbers, An introduction to international institutional law, Cambridge 2002 kap. 4.

xxii Jf Andersson, Cameron og Nordback, European Business Law Review 2003 s. 120-123.

xxiii Jf Cameron, Human Rights Law Review 2003 (2) s. 244 ved note 55.

${ }^{\text {xxiv }}$ Prinsippet er ein del av nasjonal konstitusjonell rett i dei nordiske landa, og er også nedfelt i den europeiske menneskerettskonvensjonen (EMK) art. 7.

${ }^{x x v}$ Sjå note 12 framanfor.

xxvi Jf Vang, Straffansvar for finansiering av terrorisme, Stor særavhandling, Universitetet i Troms $\emptyset$, Det juridiske fakultet nr 129, Troms $\varnothing 2003$ s. 57-58.

xxvii Jf Strandbakken, Uskyldspresumsjonen : "In dubio pro reo", Bergen 2003 s. 27.

xxviii Jf De Wet, The chapter VII powers of the United Nations Security Council, Oxford 2004 s. 353.

${ }^{x x i x}$ Då forslaget til reglane om bandlegging var på høyring, peika Institutt for Menneskerettigheter (Universitet i Oslo) på at eit vedtak om bandlegging må reknast som "criminal charge" i relasjon til EMK art. 6, jf Hegge, Mennesker \& Rettigheter 2002 (2) s. 89-90 og Ot.prp. nr. 61 (2001-2002) s. 63.

xxx Jf den langt meir utførlege diskusjonen hjå Andersson, Cameron og Nordback, European Business Law Review 2003 s. 111-141, Cameron, Nordic Journal of International Law 2003 (2) s. 159-214 og Cameron, Human Rights Law Review 2003 (2) s. 225-256.

xxxi Jf Andersson, Cameron og Nordback, European Business Law Review 2003 s. 124 som samaliknar det med "an imperial Roman proscription".

xxxii Jf Common Position 2001/931/CFSP art. 4 (OJ 2001 L 344/93).

xxxiii Jf Cameron, Human Rights Law Review 2003 (2) s. 255.

xxxiv I Sverige vart Riksdagen si rolle ytterlegare svekt ved at regjeringa let vera å leggja fram eit konkret lovforslag samtidig som Riksdagen skulle godkjenna rammeavgjerda. Jf lagrådet sine merknader i bilag 6 til Prop. 2002/03:38 samt diskusjonen i Justitieutskottets betänkande 2001/02:JuU22.

${ }_{\text {xxxv }}$ Dersom terrorhandlinga er gjort i utlandet av ein utlending, skal tiltalespørsmålet etter norsk rett avgjerast av Kongen (i Statsråd), jf straffelova § 13.

xxxvi Jf Cameron, Nordic Journal of International Law 2003 (2) s. 211-213, som peikar på at ein kan byggja inn eit prinsipp om gjensidig anerkjenning av slike avgjerder, etter mønster av ulike EUrammeavgjerder om gjensidig anerkjenning av vedtak i straffesaker.

\section{Adresse:}

Universitetet i Bergen

Det juridiske fakultet

Magnus Lagabøtes pl. 1

5010 Bergen

E-post: husabo@jur.uib.no 